\title{
LONG-TERM C-CO 2 EMISSIONS AND CARBON CROP RESIDUE MINERALIZATION IN AN OXISOL UNDER DIFFERENT TILLAGE AND CROP ROTATION SYSTEMS ${ }^{(1)}$
}

\author{
Ben-Hur Costa de Campos ${ }^{(2)}$, Telmo Jorge Carneiro Amado(3), Carlos Gustavo \\ Tornquist $^{(4)}$, Rodrigo da Silveira Nicoloso ${ }^{(5)}$ \& Jackson Ernani Fiorin ${ }^{(6)}$
}

\begin{abstract}
Soil C- $\mathrm{CO}_{2}$ emissions are sensitive indicators of management system impacts on soil organic matter ( $\mathrm{SOM})$. The main soil $\mathrm{C}-\mathrm{CO}_{2}$ sources at the soil-plant interface are the decomposition of crop residues, SOM turnover, and respiration of roots and soil biota. The objectives of this study were to evaluate the impacts of tillage and cropping systems on long-term soil $\mathrm{C}_{-} \mathrm{CO}_{2}$ emissions and their relationship with carbon (C) mineralization of crop residues. A long-term experiment was conducted in a Red Oxisol in Cruz Alta, RS, Brazil, with subtropical climate Cfa (Köppen classification), mean annual precipitation of 1,774 $\mathrm{mm}$ and mean annual temperature of $19.2^{\circ} \mathrm{C}$. Treatments consisted of two tillage systems: (a) conventional tillage (CT) and (b) no tillage (NT) in combination with three cropping systems: (a) R0- monoculture system (soybean/wheat), (b) R1- winter crop rotation (soybean/wheat/soybean/black oat), and (c) R2- intensive crop rotation (soybean/ black oat/soybean/black oat + common vetch/maize/oilseed radish/wheat). The soil C-CO $\mathrm{CO}_{2}$ efflux was measured every 14 days for two years (48 measurements), by trapping the $\mathrm{CO}_{2}$ in an alkaline solution. The soil gravimetric moisture in the 0-0.05 m layer was determined concomitantly with the $\mathrm{C}_{-} \mathrm{CO}_{2}$ efflux measurements. The crop residue $\mathrm{C}$ mineralization was evaluated with the mesh-bag method, with sampling 14, 28, 56, 84, 112, and 140 days after the beginning of the evaluation period for $\mathrm{C}$ measurements. Four $\mathrm{C}$ conservation indexes were used to assess the relation between $\mathrm{C}_{-} \mathrm{CO}_{2}$ efflux and soil $\mathrm{C}$ stock and its compartments. The crop
\end{abstract}

(1) Part of the Ph.D. Thesis of the first author presented at the Soil Science Post-Graduation Program of the Federal University of Santa Maria, UFSM. Received for publication in February 2010 and approved in March 2011.

(2) Professor, Federal Institute of Rio Grande do Sul, Ibirubá Campus, IFRS. 1111 Nelsi Fritsch Road, CEP 98200-000 Ibirubá (RS) Brazil. E-mail: ben-hur.campos@ibiruba.ifrs.edu.br

(3) Associate Professor, Soil Department, UFSM. 1000 Roraima Ave., CEP 97105-900 Santa Maria (RS) Brazil. CNPq Scholarship. E-mail: tamado@smail.ufsm.br

(4) Adjunct Professor, Soil Department, Federal University of Rio Grande do Sul, UFRGS. 7712 Bento Gonçalves Ave., CEP 91540-000 Porto Alegre (RS) Brazil. E-mail: carlos.tornquist@ufrgs.br

(5) Researcher, Embrapa Swine and Poultry. Road BR 153 km 110, P.O. BOX 21, CEP 89700-000 Concórdia (SC) Brazil. CAPES/ PNPD Scholarship. E-mail: rodrigo.nicoloso@cnpsa.embrapa.br

(6) Researcher, Foundation Center of Experimentation and Research, FUNDACEP. Professor, Cruz Alta University, UNICRUZ. Road RS 342 Km 149, CEP 98100-970 Cruz Alta (RS) Brazil. E-mail: jackson@fundacep.com.br 
residue $\mathrm{C}$ mineralization fit an exponential model in time. For black oat, wheat and maize residues, $\mathrm{C}$ mineralization was higher in CT than NT, while for soybean it was similar. Soil moisture was higher in NT than CT, mainly in the second year of evaluation. There was no difference in tillage systems for annual average $\mathrm{C}-\mathrm{CO}_{2}$ emissions, but in some individual evaluations, differences between tillage systems were noticed for $\mathrm{C}-\mathrm{CO}_{2}$ evolution. Soil $\mathrm{C}-\mathrm{CO}_{2}$ effluxes followed a bi-modal pattern, with peaks in October/November and February/March. The highest emission was recorded in the summer and the lowest in the winter. The $\mathrm{C}-\mathrm{CO}_{2}$ effluxes were weakly correlated to air temperature and not correlated to soil moisture. Based on the soil $\mathrm{C}$ conservation indexes investigated, NT associated to intensive crop rotation was more $\mathrm{C}$ conserving than $\mathrm{CT}$ with monoculture.

Index terms: management systems, no tillage, conventional tillage, greenhouse gases.

RESUMO: EMISSÕES DE C-CO $\mathrm{O}_{2}$ DE LONGO PRAZO E A MINERALIZAÇÃO DO CARBONO DOS RESÍDUOS CULTURAIS EM UM LATOSSOLO SOB DIFERENTES SISTEMAS DE PREPARO E ROTAÇÃO DE CULTURAS

\begin{abstract}
A emissão de $\mathrm{C}-\mathrm{CO}_{2}$ do solo é considerada um indicador sensível dos impactos de sistemas de manejo sobre a matéria orgânica do solo (MOS). Nos sistemas agrícolas, as principais fontes de $\mathrm{C}-\mathrm{CO}_{2}$ são as decomposições dos resíduos culturais e da MOS, além da respiração das raizes das culturas e da biota do solo. O principal objetivo deste estudo foi avaliar o impacto de sistemas de preparo do solo e culturas nas emissões de longo prazo de C-CO $\mathrm{C}_{2}$ do solo e sua relação com a mineralização do carbono $(C)$ de resíduos culturais. Este estudo foi desenvolvido em experimento de longa duração, em Latossolo Vermelho distrófico típico, de ocorrência na região de Cruz Alta, RS, Brasil. O clima é o subtropical Cfa, segundo a classificação de Köppen, com precipitação pluvial anual média de $1.744 \mathrm{~mm}$ e temperatura média anual de $19,2^{\circ} \mathrm{C}$. Os tratamentos investigados foram dois sistemas de preparo-convencional $(P C) e$ plantio direto $(P D)$ - e três sistemas de culturas: RO- sucessão de monoculturas (trigo/soja); R1- rotação de culturas de inverno (aveia-preta / soja /trigo / soja); e R2-rotação intensiva de culturas (aveia-preta/soja/aveia-preta+ervilhaca/milho / nabo forrageiro/trigo/soja). O efluxo de $\mathrm{C}-\mathrm{CO}_{2}$ do solo foi avaliado em intervalos fixos de 14 dias, durante dois anos (48 avaliações), por meio da captura do dióxido de carbono em solução alcalina. A umidade gravimétrica do solo, na camada de 0-0,05 m, foi determinada concomitantemente com as medições de $\mathrm{C}-\mathrm{CO}_{2}$. Ainda, foi avaliada a taxa de liberação do $\mathrm{C}$ dos resíduos culturais utilizando o método dos sacos de decomposição, com amostragens aos 14, 28, 56, 84, 112 e 140 dias após o início das avaliações de mineralização do C. Foram utilizados quatro índices de conservação do C para avaliar a relação entre as emissões de $\mathrm{C}_{-} \mathrm{CO}_{2}$ e estoques de $\mathrm{Ce}$ seus compartimentos no solo. A mineralização do $C$ dos resíduos culturais no tempo seguiu o modelo exponencial. Para os residuos de aveia-preta, trigo e milho, a mineralização do $C$ foi maior no $C T$ do que no $P D$, enquanto para a soja foi semelhante entre os sistemas de preparo do solo. A umidade do solo foi maior sob PD do que no PC, especialmente no segundo ano de avaliação. Não houve diferença na emissão média anual de $\mathrm{C}-\mathrm{CO}_{2}$ entre sistemas de preparo; diferenças foram observadas apenas em algumas avaliações individuais. As emissões de C$\mathrm{CO}_{2}$ seguiram padrão bimodal, com picos nos meses de outubro-novembro e fevereiro-março. As maiores emissões de $\mathrm{C}$ - $\mathrm{CO}_{2}$ foram registradas no verão, e as menores, no inverno. As emissões de $\mathrm{C}-\mathrm{CO}_{2}$ apresentaram baixa correlação com a temperatura do ar e não foram influenciadas pela umidade do solo. Com base nos índices de conservação de C investigados, o PD associado à rotação intensiva de culturas foi mais conservador de C do que o PC com sucessão de culturas.
\end{abstract}

Termos de indexação: sistemas de manejo, plantio direto, preparo convencional, gases de efeito estufa. 


\section{INTRODUCTION}

The greenhouse effect is a natural phenomenon responsible for the partial retention of the incident solar radiation on the earth surface, maintaining the global mean temperature close to $15^{\circ} \mathrm{C}$ (IPCC, 2001). However, the increase of greenhouse gas (GG) concentrations in the last century has amplified this natural effect and, consequently, raised the global mean temperature. In developed countries, the increase of GG concentrations has been associated to industry and transportation sectors due to fossil fuel consumption (IPCC, 2007). In developing countries, changes in land use and agricultural activities have been considered important sources of GGs. In Brazil, these latter are the major sources of GGs because of the high deforestation rates associated with frequent biomass burning and high SOM decomposition rates resulting of the soil mobilization under conventional tillage (Cerri \& Cerri, 2007). Possible consequences of climate changes for Brazil include yield loss in the major grain and cash crops (Siqueira et al., 2001; Streck, 2005).

Soil organic matter, consisting mostly of $\mathrm{C}$, is the largest terrestrial pool in the $\mathrm{C}$ biogeochemical cycle (IPCC, 2001). Although SOM rarely accounts for more than $5 \%$ of the soil volume, it plays a crucial role in soil physical, chemical and biological properties associated with crop yields and soil degradation resistance (Brady, 1989; Conceição et al., 2005; Manlay et al., 2007). Therefore, the agricultural systems that are able to increase the soil $\mathrm{C}$ stocks could contribute to maintain soil productivity and, at the same time, mitigate global warming. In this context, conservation tillage systems have been emphasized as an important tool to increase the soil C sink (Franzluebbers et al., 1994; Bayer et al., 2000; West \& Post, 2002; Amado et al., 2006). In the context of the project of low carbon agriculture, recently launched by the Brazilian government, it was estimated that the increase of the current NT area from 28 million ha to 40 million ha in 2020 , could represent the removal of 224 million tons of atmospheric $\mathrm{CO}_{2}$ (Brasil, 2009).

The increase in soil organic $\mathrm{C}$ stock (SOC) is a result of a positive balance between $\mathrm{C}$ inputs, derived from above and belowground biomass, and $\mathrm{C}$ outputs, mainly associated to heterotrophic decomposition of SOM and soil erosion (Anderson, 1982; Stevenson, 1994; Franzluebbers et al., 1994; Kuzyakov, 2006). Crop residues and SOM, especially the labile pools, are used as energy source by the microbial biomass. Most of this $\mathrm{C}$ is lost as C-CO $\mathrm{CO}_{2}$ during the decomposition process (Vargas \& Scholles, 2000; Moreira \& Siqueira, 2002). Other soil C-CO ${ }_{2}$ sources include plant root metabolism and the respiration of rhizosphereassociated microorganisms (Mielnick, 1996). These soil C-CO $\mathrm{CO}_{2}$ effluxes are regulated by climatic conditions, especially temperature and soil moisture (Buyanovsky et al., 1986; Rees et al., 2005).
Crop decomposition begins with residue fragmentation by soil fauna and subsequent microbial activity. Residue decomposition is mainly regulated by climatic conditions, soil nutrient availability and the biochemical composition of the residues, such as lignin and alkaloid contents and $\mathrm{C} / \mathrm{N}$ ratio (Rees et al., 2005; Padovan et al., 2006). In field studies of crop residue decomposition under soil tillage systems, mesh-bags are frequently applied (Wieder \& Land, 1982; Amado et al., 2003; Padovan et al., 2006; De Bona et al., 2006).

Soil C- $\mathrm{CO}_{2}$ emission is a sensitive indicator of changes in microbial biomass induced by soil management systems, and, therefore, it is important to understand the crop residue and SOM dynamics (Campbell et al., 1991; Franzluebbers et al., 1995; Vargas \& Scholles, 2000; Costa et al., 2008). Measurements of in vitro $\mathrm{C}-\mathrm{CO}_{2}$ emission could be more precise than in situ because the variability associated with microclimatic factors is reduced and the analytical procedures are simplified. However, laboratory handling for these measurements could affect the representativeness of the soil management systems such as soil tillage and cropping systems. Therefore, in situ assessments of C-CO $\mathrm{CO}_{2}$ efflux have been preferred for the study of microbial activity, crop residue decomposition and SOM dynamics under soil management systems (Franzluebbers et al., 1995; Magid et al., 1997; Costa et al., 2006).

Conventional tillage causes physical fractionation of crop residues, increases the soil-residue contact, soil aeration and temperature, and leads to in an increase in crop residue decomposition rates that follows the exponential model decay (Amado et al., 2000; Aita \& Giacomini, 2007). on the other hand, no tillage maintains crop residues on the soil surface, promotes minimum soil disturbance limiting the soilresidue contact resulting in a reduced crop residue decomposition rate (Amado et al., 2003). The $\mathrm{C}-\mathrm{CO}_{2}$ emissions are regulated by $\mathrm{C}$ crop residue input (Franzlubbers et al., 1995; Mielnick, 1996). Tillage and cropping systems also affect the microbial ecology and activity (Vargas \& Scholles, 2000). Comparing long-term NT in Paraná State, Siqueira Neto et al. (2009) reported that the increase in time of NT adoption from 12 to 22 years resulted in higher C$\mathrm{CO}_{2}$ emissions. In that study, it was observed that the seasonal C- $\mathrm{CO}_{2}$ emissions followed the temperature fluctuation during the year, i.e., in months with low temperature, as in July, C- $\mathrm{CO}_{2}$ emission was only $40 \%$ of the months with high temperature, as in October. Similarly, Costa et al. (2008), in Rio Grande do Sul State, reported that in the winter, at an average minimum temperature of $8{ }^{\circ} \mathrm{C}, \mathrm{C}-\mathrm{CO}_{2}$ emission was $20 \%$ of the summer emissions, with an average maximum temperature of $38^{\circ} \mathrm{C}$.

The $\mathrm{C}$ retention index was investigated in a longterm experiment in Rio Grande do Sul State, Costa et al. (2008) reported that NT of legume cover crop 
(vetch/maize) increases $\mathrm{C}$ retention in relation to $\mathrm{CT}$ with grass crop succession (black oat/maize). Information regarding the $\mathrm{C}$ retention index in tillage and crop systems in Southern Brazil is still limited.

This study aimed to evaluate the effect of tillage systems on crop residue carbon mineralization of main cash and cover crops regularly used in Southern Brazil. In addition, it investigated the long-term in situ $\mathrm{C}-\mathrm{CO}_{2}$ emissions as affected by abiotic factors, tillage systems and crop residue type. Finally, the carbon management index was also determined, based on the annual C- $\mathrm{CO}_{2}$ emission and its relation with soil $\mathrm{C}$ stock and $\mathrm{C}$ crop input in a long-term experiment conducted in a grain-producing region of Southern Brazil, on an Oxisol.

\section{MATERIAL AND METHODS}

\section{Soil and climate characteristics}

Described by Campos et al. (2011).

\section{Weather conditions in the experimental period}

Precipitation distribution and air temperature in the studied period are presented in figure 1. As expected for subtropical climate, the mean temperature was lower in the winter and higher in the summer, with intermediate values in autumn and spring. The mean winter was about half of the mean summer temperature. The first year had a colder winter, with a $22 \%$ lower mean temperature than in the second year. Also, the summer in the first was drier than in the second year, with $45 \%$ lower precipitation. In the second year, a linear relationship $(r=0.73)$ between rainfall precipitation and air temperature was noted. These abiotic factors would probably sustain an increase of biological activity and, therefore, $\mathrm{C}-\mathrm{CO}_{2}$ efflux in the second year compared to the first year.

\section{Long-term C-CO $\mathrm{CO}_{2}$ emissions}

Soil C-CO $\mathrm{CO}_{2}$ efflux was assessed by the method of C$\mathrm{CO}_{2}$ trapping in a sodium hydroxide solution with static chambers described by Anderson (1982), with modifications proposed by Franzluebbers et al. (1995). The evaluation period was from June 1999 to June 2001 , corresponding to the $14^{\text {th }}$ to $16^{\text {th }}$ experimental year. Five cylindrical PVC chambers (height $0.3 \mathrm{~m}$, $\varnothing 0.15 \mathrm{~m}$ ) were randomly placed on the experimental plots and pushed into the soil to a depth of approximately $0.04 \mathrm{~m}$ between the crop rows. Laboratory flasks (height $0.15 \mathrm{~m}, \varnothing 0.10 \mathrm{~m}$ ) containing $20 \mathrm{~mL}$ of $\mathrm{NaOH} 1 \mathrm{~mol} \mathrm{~L}^{-1}$ solution were placed in the chambers on a supporting wire-mesh structure about $0.03 \mathrm{~m}$ above the soil surface. Three control chambers with closed bottom were also placed in the field as blanks.

Soil C- $\mathrm{CO}_{2}$ efflux was assessed in an evaluation period of $24 \mathrm{~h}$, starting at 2:00 PM and finishing $24 \mathrm{~h}$ later. The measurements were repeated within fixed time intervals of 14 days for two years, totalizing 48 measurements. After the evaluation period, the flasks with the alkaline solution were removed and hermetically closed, until the titration with $\mathrm{HCl} 0.5 \mathrm{~N}$ solution in $\mathrm{BaCl}_{2}$ excess (Stotzky, 1956). The C- $\mathrm{CO}_{2}$ efflux per unit area was calculated as follows:

$$
\mathrm{C}-\mathrm{CO}_{2}=((\mathrm{B}-\mathrm{V}) \times \mathrm{M} \times \mathrm{E}) /(\mathrm{A} \times \mathrm{T})
$$

where $\mathrm{C}-\mathrm{CO}_{2}=\mathrm{C}$ efflux as $\mathrm{CO}_{2}\left(\mathrm{mg} \mathrm{m}^{-2} \mathrm{~h}^{-1}\right) ; \mathrm{B}=$ volume of $\mathrm{HCl}$ solution used for the titration of treatment samples $(\mathrm{mL}) ; \mathrm{V}=$ volume of $\mathrm{HCl}$ solution used for the titration of blank samples $(\mathrm{mL}) ; \mathrm{M}=$

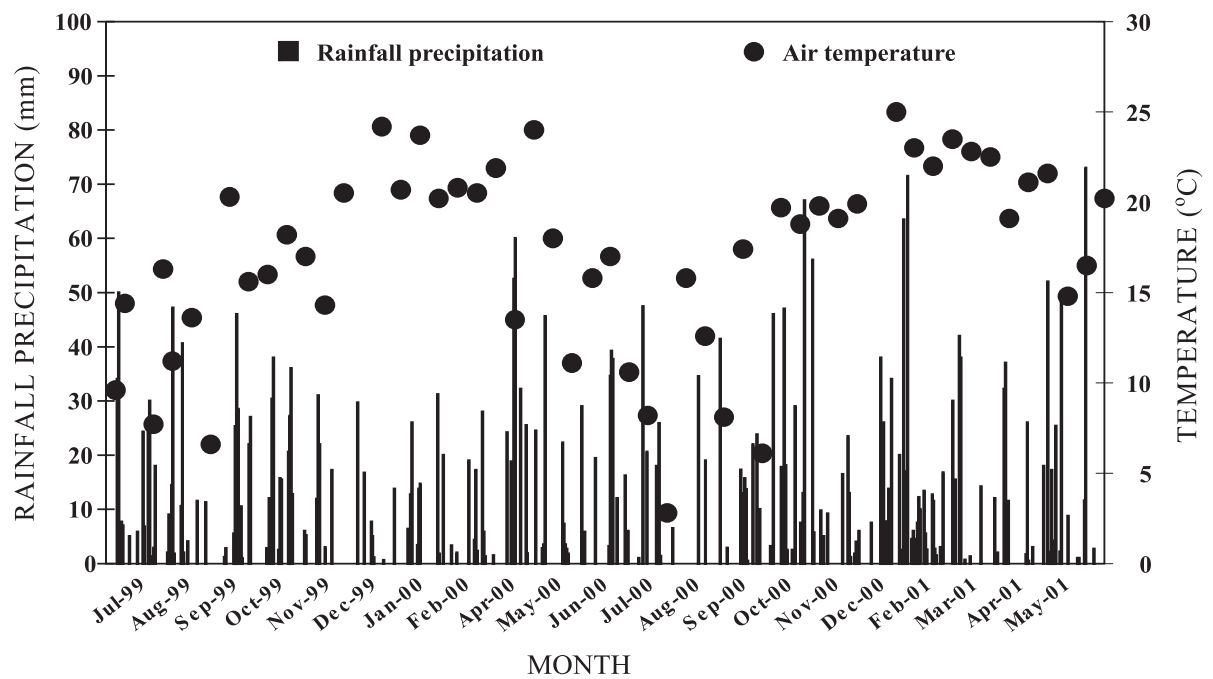

Figure 1. Rainfall precipitation and air temperature during the evaluation period of $\mathrm{CO}_{2}$ emissions (from June 7, 1999 to June 4, 2001). 
molarity $\left(\mathrm{mol} \mathrm{L}^{-1}\right)$ of the $\mathrm{HCl}$ solution; $\mathrm{E}=$ carbon gram-equivalent (6 g); $\mathrm{A}=$ exposed soil surface area $\left(\mathrm{m}^{2}\right) ; \mathrm{T}=$ sampling time $(\mathrm{h})$.

\section{Crop residue decomposition}

Crop residues for the decomposition study were collected after the harvest of the grain crops or the management of the cover crops. These crop residues were chopped in $0.05 \mathrm{~m}$ pieces and dried at $65^{\circ} \mathrm{C}$ to constant weight. The mesh-bags $(0.10 \times 0.20 \mathrm{~m})$ were made of a $50 \mu \mathrm{m}$ screen to allow access of soil mesoand macro-fauna (Amado et al., 2003; Padovan et al., 2006). In the first evaluation period (1998/1999), the mesh-bags were filled with an equal amount of crop residues for all treatments. In the second period (1999 and 1999/2000), the amount of crop residues placed in the mesh-bags was proportional to the amount of dry biomass produced in each plot. Six mesh-bags were placed per plot on the soil surface in NT and at a depth of $0.10 \mathrm{~m}$ in the CT. The mesh-bags were removed $14,28,56,84,112$, and 140 days after the beginning of the decomposition study. The remaining crop residues inside the mesh-bags were dried at $65^{\circ} \mathrm{C}$ and attached soil was gently removed. Roots that grew into the mesh-bags were also removed. The $\mathrm{C}$ content of the crop residue samples was determined by sulfochromic digestion with external heating, as described by Tedesco et al. (1995). The decay rates of the $\mathrm{C}$ in the crop residues were adjusted by the onecompartmental exponential model, as proposed by Wieder \& Land (1982) and Whitmore (1996), and described as follows:

$$
\mathrm{Y}=\mathrm{C}_{0} \mathrm{e}^{-\mathrm{kt}}
$$

where $\mathrm{Y}=$ remaining $\mathrm{C}\left(\mathrm{kg} \mathrm{ha}^{-1}\right) ; \mathrm{C}_{0}=$ initial $\mathrm{C}\left(\mathrm{kg} \mathrm{ha}^{-1}\right)$; $\mathrm{K}=$ decay constant rate; $\mathrm{t}=$ time (day).

The half-life $\mathrm{C}$ of the crop residues, or the time necessary for release of $50 \%$ of the initial amount of C, was calculated as proposed by Paul \& Clark (1989), and described as following:

$$
\mathrm{t}_{1 / 2}=(\ln 2) / \mathrm{k}
$$

where $\mathrm{t}_{1 / 2}=$ half-life; $\mathrm{k}=$ decay constant rate.

The amount of crop residue input to the soil by cropping systems was estimated by Campos (2006) and SOC, by Campos et al. (2011). Based on these data and on the C-CO $\mathrm{CO}_{2}$ efflux, four Carbon Conservation Indexes (CCIs) were calculated, as proposed by Franzluebbers et al. (1995) and Costa et al. (2008):

$$
\begin{gathered}
\mathrm{CCI} \mathrm{I}=\frac{\Delta \mathrm{SOC}}{\mathrm{C} \text {-input }} \\
\mathrm{CCI} \mathrm{II}=\frac{\mathrm{C}^{-} \mathrm{CO}_{2} \text { emissions }}{\mathrm{SOC}} \\
\mathrm{CCI} \mathrm{III}=\frac{\mathrm{C}^{-\mathrm{CO}_{2} \text { emissions }}}{\mathrm{POC}}
\end{gathered}
$$

$$
\mathrm{CCI} \text { IV }=\frac{\mathrm{C}-\mathrm{CO}_{2} \text { emissions }}{\mathrm{C} \text {-input }+ \text { SOC }}
$$

where $\Delta \mathrm{SOC}=$ mean annual change of soil organic carbon (SOC) stocks between 1995 and 2004 in the 0$0.20 \mathrm{~m}^{2}$ layer ( $\left.\mathrm{Mg} \mathrm{ha}^{-1} \mathrm{yr}^{-1}\right)$ (Campos et al., 2011); C$\mathrm{CO}_{2}$ emissions $=$ mean annual soil $\mathrm{C}-\mathrm{CO}_{2}$ efflux $\left(\mathrm{Mg} \mathrm{ha}^{-1}\right)$; C-input = carbon crop (above and belowground) input, assuming additional $30 \%$ of the aboveground $\mathrm{C}$ input for root contribution (Zanatta et al., 2007) $\left(\mathrm{Mg} \mathrm{ha}^{-1}\right) ; \mathrm{SOC}=$ SOC stock in the $0-0.20 \mathrm{~m}$ layer $\left(\mathrm{Mg} \mathrm{ha}^{-1}\right) ; \mathrm{POC}=$ Particulate organic $\mathrm{C}(\mathrm{POC})$ stock in the $0-0.10 \mathrm{~m}$ layer $\left(\mathrm{Mg} \mathrm{ha}^{-1}\right)$

\section{Meteorological data}

Precipitation and air temperature throughout the study period were obtained at the FUNDACEP meteorological station, approximately $300 \mathrm{~m}$ away from the experimental site. The soil gravimetric moisture in the $0-0.05 \mathrm{~m}$ layer was determined by sampling soil concomitantly with the $\mathrm{CO}_{2}$ efflux measurements.

\section{Statistical analysis}

Soil C- $\mathrm{CO}_{2}$ emissions were compared at each sampling using the LSD test at $5 \%$ significance. Given the high variability of the in situ $\mathrm{C}-\mathrm{CO}_{2}$ efflux measurements, which is inherent to the method used, outliers were removed by the Dixon $\mathrm{Q}$ test. The criterion for outlier elimination was a Dixon $Q$ value exceeding the critical $\mathrm{Q}$ value at $5 \%$ significance (Dixon, 1950). Soil moisture data from treatments were compared using the Student t test. The crop residue decomposition data were submitted to regression analysis by the software SigmaPlot (Systat, 2002). Analysis of variance was performed using software SAS (SAS, 1996). For a comparison of C$\mathrm{CO}_{2}$ emissions, the main sources of variation were considered significant at a level of $5 \%$ and their interactions at $10 \%$ by the $\mathrm{F}$ test. Additionally, Pearson correlation coefficients for C- $\mathrm{CO}_{2}$ efflux and soil temperature and moisture were calculated using original data.

\section{RESULTS AND DISCUSSION}

\section{Crop residue decomposition}

The crop residue decomposition rate, expressed by exponential $\mathrm{C}$ decay in both tillage systems, was assessed over three distinct periods, from November/ 1998 to April/2000 (Figure 2; Table 1). Crop residue decomposition rate has an influence on the soil cover, soil moisture and C-CO $\mathrm{CO}_{2}$ efflux (Amado et al., 1990; Mielnick, 1996). In the first period from November/ 1998 to April/1999, with winter crop residue input, the composition of the cover crop consortium (R2) 
showed a predominance of black oat over common vetch. Wheat in the cropping system $\mathrm{R} 0$ and black oat in $\mathrm{R} 1$ produced a higher $\mathrm{C}$ input than black oat + vetch in the R2 cover crop consortium. This result was not expected but some irregular crop growth among treatments had been previously noticed in the experimental period. The $\mathrm{C}$ decay rates for these winter crops in the same tillage system were similar, ranging from 4.8 to $5.6 \mathrm{~kg} \mathrm{ha}^{-1}$ day $^{-1} \mathrm{C}$ in NT and from 12.2 to $12.8 \mathrm{~kg} \mathrm{ha}^{-1}$ day $^{-1} \mathrm{C}$ in CT (Table 1). This result is partially explained by the predominance of grass crop (black oat and wheat) addition to the soil. For these crops, the $\mathrm{C}$ decay rate under $\mathrm{CT}$ was about twice as high as in NT. Therefore, the half-life of black oat residues (R1) was 54 and 124 days for CT and NT, respectively, while the half-life of wheat residues (R0) was 57 (CT) and 139 (NT) days.

The $\mathrm{C}$ decay rate of black oat under NT (R1) of $4.8 \mathrm{~kg} \mathrm{ha}^{-1}$ day $^{-1} \mathrm{C}$ observed in this study is similar to findings reported by $\mathrm{Da}$ Ros et al. (2004), who observed a rate of $4.7 \mathrm{~kg} \mathrm{ha}^{-1} \mathrm{day}^{-1} \mathrm{C}$ under the same climate and soil conditions. However, De Bona et al. (2006) reported black oat decomposition rates under NT of 6.7 and $11.0 \mathrm{~kg} \mathrm{ha}^{-1}$ day $^{-1} \mathrm{C}$ in non-irrigated and irrigated areas, respectively. These higher $\mathrm{C}$ mineralization rates of black oat could be associated to diverse climatic conditions of that study in relation to our study, markedly the higher mean air temperature.

In the second evaluation period (April/1999 to September/1999), with summer crop residue input of maize, a C decay rate under CT $\left(11.1 \mathrm{~kg} \mathrm{ha}^{-1}\right.$ day $\left.^{-1} \mathrm{C}\right)$ about twice as high as in NT $\left(5.1 \mathrm{~kg} \mathrm{ha}^{-1}\right.$ day $\left.^{-1} \mathrm{C}\right)$ was also observed. On the other hand, for soybean residues the $\mathrm{C}$ decay rates were similar in the tillage systems (R0 CT=8.6 and NT=7.9 kg ha-1 day $^{-1} \mathrm{C}$; R1 CT=8.4 and NT=8.5 kg ha ${ }^{-1}$ day $^{-1} \mathrm{C}$ ). The $\mathrm{C}$ half-life for maize residues was 62 and 136 days for CT and NT, respectively, while for soybean residues it ranged from 81 to 88 days, with an average over tillage systems of 83 days. Therefore, the $\mathrm{C}$ decay rates were influenced by the interaction of tillage and cropping systems. This result is in agreement with Aita \& Giacomini
R0

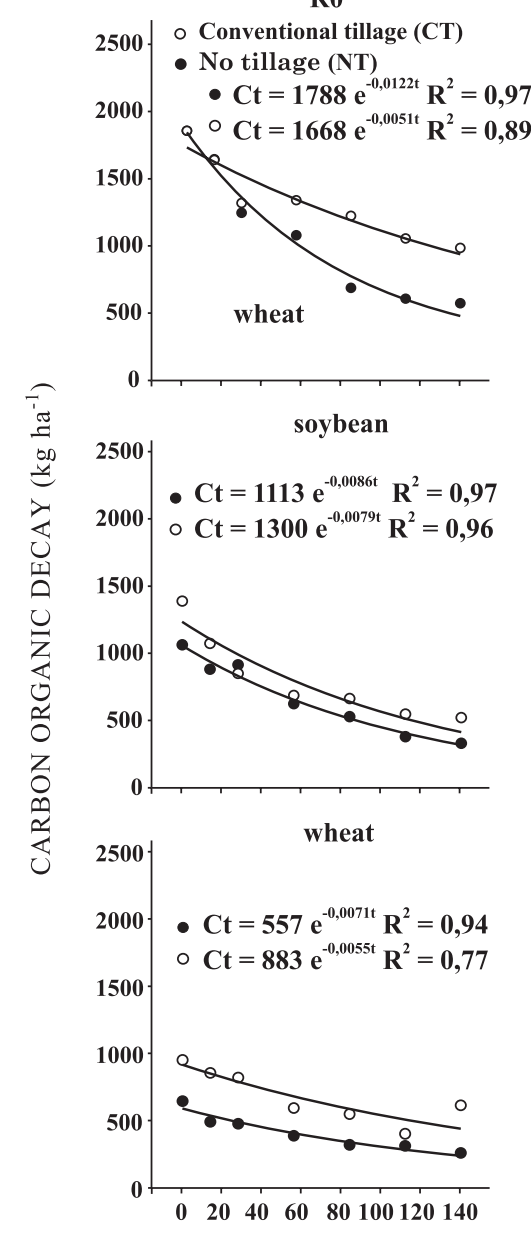

R1

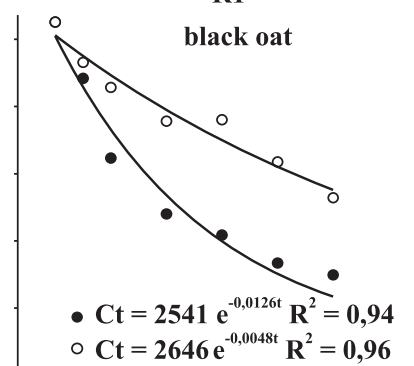

○ $C t=2646 \mathrm{e}^{-0,0048 t} R^{2}=0,96$

soybean

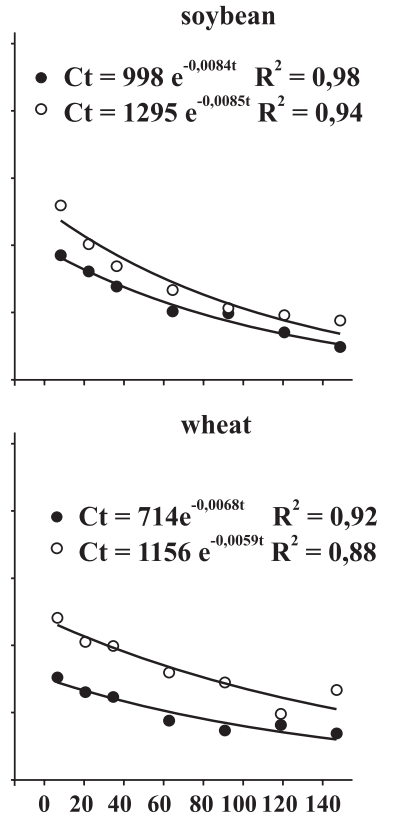

DAY OF C EVALUATION
R2
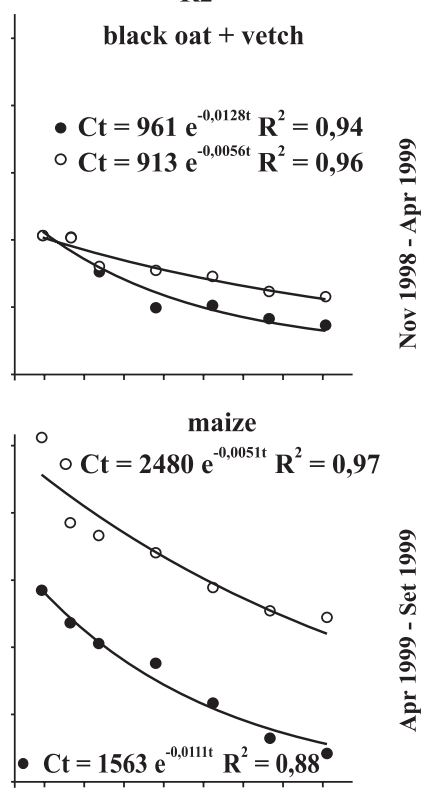

wheat

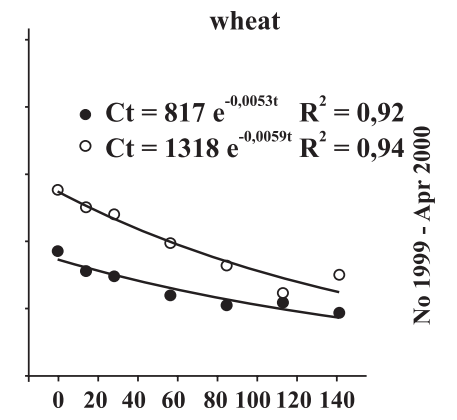

Figure 2. Carbon decay $(\mathrm{Ct})$ of crop residue adjusted to a negative exponential model $\left(\mathrm{Y}=\mathrm{C}_{\mathrm{o}} \mathrm{e}^{-\mathrm{kt}}\right)$ under conventional tillage (CT) and no tillage (NT) and cropping systems (R0: soybean/wheat; R1: soybean/ wheat/soybean/black oat; R2: soybean/black oat/soybean/black oat+ common vetch/maize/oilseed radish/ wheat) during three periods of evaluation. 
Table 1. Initial $C\left(C_{0}\right)$, decay constant rate $(k)$, determination coefficient $\left(R^{2}\right)$ and half-life $\left(t_{1 / 2}\right)$ of crop residues in mesh-bags under influence of two soil tillage systems $(\mathrm{CT}=$ conventional tillage and $\mathrm{NT}=\mathrm{no}$ tillage) and three cropping systems (R0: soybean/wheat; R1: soybean/wheat/soybean/black oat; R2: soybean/black oat/soybean/black oat+ common vetch/maize/oilseed $\mathrm{radish} / \mathrm{wheat}$ ), from November 1998 to April 2000

\begin{tabular}{|c|c|c|c|c|c|c|}
\hline Tillage system & Cropping system & Crop residue & $\mathbf{C}_{0}$ & $\mathbf{k}$ & $\mathbf{R}^{2}$ & $t_{1 / 2}$ \\
\hline & & & $\mathrm{kg} \mathrm{ha}^{-1}$ & $\mathrm{~kg} \mathrm{ha}^{-1}$ day $^{-1}$ & & day $^{-1}$ \\
\hline & \multicolumn{6}{|c|}{ November 1998 - April 1999} \\
\hline $\mathrm{CT}$ & R0 & Wheat & 1,788 & 12.2 & 0.97 & 57 \\
\hline NT & & & 1,668 & 5.1 & 0.89 & 139 \\
\hline $\mathrm{CT}$ & $\mathrm{R} 1$ & Black oat & 2,541 & 12.6 & 0.94 & 55 \\
\hline NT & & & 2,646 & 4.8 & 0.96 & 144 \\
\hline $\mathrm{CT}$ & R2 & Black oat+vetch & 961 & 12.8 & 0.94 & 54 \\
\hline \multirow[t]{2}{*}{ NT } & & & 913 & 5.6 & 0.93 & 124 \\
\hline & \multicolumn{6}{|c|}{ April 1999 - September 1999} \\
\hline $\mathrm{CT}$ & R0 & Soybean & 1,113 & 8.6 & 0.97 & 88 \\
\hline NT & & & 1,300 & 7.9 & 0.88 & 81 \\
\hline CT & $\mathrm{R} 1$ & Soybean & 998 & 8.4 & 0.98 & 81 \\
\hline NT & & & 1,295 & 8.5 & 0.94 & 82 \\
\hline $\mathrm{CT}$ & $\mathrm{R} 2$ & Maize & 1,563 & 11.1 & 0.88 & 62 \\
\hline \multirow[t]{2}{*}{ NT } & & & 2,480 & 5.1 & 0.97 & 136 \\
\hline & \multicolumn{6}{|c|}{ November 1999 - April 2000} \\
\hline $\mathrm{CT}$ & R0 & Wheat & 557 & 7.1 & 0.94 & 81 \\
\hline NT & & & 883 & 5.5 & 0.77 & 126 \\
\hline $\mathrm{CT}$ & $\mathrm{R} 1$ & Wheat & 714 & 6.8 & 0.92 & 63 \\
\hline NT & & & 1,156 & 5.9 & 0.88 & 136 \\
\hline $\mathrm{CT}$ & $\mathrm{R} 2$ & Wheat & 817 & 5.3 & 0.92 & 82 \\
\hline NT & & & 1,318 & 5.9 & 0.94 & 117 \\
\hline
\end{tabular}

(2007), who noted that the effect of soil tillage on increasing crop residue decomposition was more pronounced for aboveground crop residues with high $\mathrm{C} / \mathrm{N}$ ratio. Intensive soil mobilization under $\mathrm{CT}$ leads to shredding of the crop residues and increases the soil-residue contact, concurrently increasing soil aeration and soil temperature, which leads to faster residue decomposition. Conversely, crop residues under NT are maintained at the soil surface with less soil-residue contact, with greater exposure of residues to drying and wetting cycles. These combined conditions decreased crop residue carbon mineralization rate in NT, especially for plants rich in recalcitrant components.

In the third period (November/1999 to April/2000), the same winter crop (wheat) was grown in the three cropping systems. In this period, the monoculture system (R0) produced about $50 \%$ less wheat biomass than the crop rotation systems (R1 and R2), in the same tillage system. Wheat monoculture in Southern Brazil increased the risk of plant diseases, resulting in a reduced mean biomass yield (Campos et al., 2011). Carbon decay rates for wheat residues ranged from 5.3 to $7.1 \mathrm{~kg} \mathrm{ha}^{-1} \mathrm{day}^{-1} \mathrm{C}$ under $\mathrm{CT}$ and 5.5 to $5.9 \mathrm{~kg} \mathrm{ha}^{-1}$ day $^{-1} \mathrm{C}$ under NT. Wheat residue $\mathrm{C}$ halflife was 75.3 and 126.3 days under CT and NT, respectively, averaged over cropping systems. In conclusion, $\mathrm{C}$ decay from recalcitrant crop residues, such as wheat and maize under CT, was about twice as high as observed under NT. On the other hand, C decay was similar across tillage systems for the less recalcitrant crop residues, such as soybean. Also, as expected, C decay of grass crops was lower than of soybean.

In the State of Rio de Janeiro, Brazil, a soybean C residue mineralization rate of $14.7 \mathrm{~kg} \mathrm{ha}^{-1} \mathrm{day}^{-1} \mathrm{C}$ under NT was reported by Padovan et al. (2006). This rate is about twice the $\mathrm{C}$ decay rate estimated in this study (8.2 kg ha-1 day $\left.^{-1} \mathrm{C}\right)$. The higher $\mathrm{C}$ mineralization rate verified in the referred study was probably associated with its tropical climate $\left(24.5^{\circ} \mathrm{C}-\right.$ mean annual temperature) in comparison to the subtropical climate of this study $\left(19.2^{\circ} \mathrm{C}\right.$ - mean temperature). Canalli (2009) reported soybean $\mathrm{C}$ mineralization rates of $6.0 \mathrm{~kg} \mathrm{ha}^{-1}$ day $^{-1} \mathrm{C}$ in Campos Gerais of the state of Parana, Southern Brazil, where the mean temperature is $18{ }^{\circ} \mathrm{C}$. The $\mathrm{C}$ mineralization rate of maize of $4.0 \mathrm{~kg} \mathrm{ha}^{-1}$ day $^{-1} \mathrm{C}$ under NT reported in that study is similar to the rate observed in this study (5.1 kg ha ${ }^{-1}$ day $^{-1} \mathrm{C}$ ). These results suggest that $\mathrm{C}$ decay of less recalcitrant crop residues such as soybean under NT was more affected by air temperature (abiotic factor) than more recalcitrant crop residues such as maize.

\section{Soil moisture in the $\mathrm{C}-\mathrm{CO}_{2}$ evaluation period}

Soil moisture during the period of June/1999 to June/2001 followed as expected the observed precipitation regime (Figure 1); therefore, it was 
higher in the second year than in the first. Soil moisture was higher in NT than CT, as previously reported by Amado et al. (1990) and Franzluebbers et al. (1995) (Figure 2). This result is related to the longer half-life of crop residues under NT than CT (Table 1). In an interannual comparison between NT and CT treatments, the differences in soil moisture were higher in the second year. Thus, in the summer of the second year, the average soil moisture in NT was $32 \%$ higher than $\mathrm{CT}$, while in the first year this difference was only $9 \%$. This result evidenced that NT is more efficient in storing water and conserve soil moisture than CT, especially under higher rainfall occurrence. The observed temporal variation in temperature and rainfall during the experimental period is typical of Southern Brazil, with a marked effect on key biological processes that regulate $\mathrm{C}-\mathrm{CO}_{2}$ effluxes, such as plant growth, plant and soil biota respiration, biomass production, crop residue decomposition rates, and SOM turnover. Therefore, the long-term $\mathrm{C}-\mathrm{CO}_{2}$ emissions in this region based on the temporal variation should be evaluated in different tillage and cropping systems.

\section{$\mathrm{C}-\mathrm{CO}_{2}$ efflux from tillage and cropping systems}

Carbon dioxide effluxes in tillage and cropping systems based on daily measurements at fixed interval (every 14 days) are shown in figure 4 . Assuming that the higher crop residue $\mathrm{C}$ decay rates under $\mathrm{CT}$ than NT verified from November/1998 to April/2000 were representative of the whole experimental period, the influence of residue decay rates on long-term $\mathrm{C}-\mathrm{CO}_{2}$ efflux from tillage systems (June/1999 to June/2001) was apparently small. Previously, Franzluebbers et al. (1995), Vargas \& Scholles (2000) and Costa et al. (2008) also reported similar soil C-CO $\mathrm{CO}_{2}$ efflux from tillage systems in long-term experiments. In the present study, the highest daily emission was $2.18 \mathrm{~kg} \mathrm{ha}^{-1} \mathrm{~h}^{-1} \mathrm{C}-\mathrm{CO}_{2}$ (January 2001) from CT with intensive crop rotation (R2) and the lowest emission was $0.10 \mathrm{~kg} \mathrm{ha}^{-1} \mathrm{~h}^{-1} \mathrm{C}-\mathrm{CO}_{2}$ (June 1999) from NT and monoculture system (R0). In the 1999/2000 growing season, the average emissions of CT and NT were 0.75 and $0.80 \mathrm{~kg} \mathrm{ha}^{-1} \mathrm{~h}^{-1} \mathrm{C}-\mathrm{CO}_{2}$, respectively, and 1.28 and $1.27 \mathrm{~kg} \mathrm{ha}^{-1} \mathrm{~h}^{-1} \mathrm{C}-\mathrm{CO}_{2}$ for the same treatments in the 2000/2001 growing season (Table 1). These results are in agreement with climate conditions reported previously and with other studies carried out with C- $\mathrm{CO}_{2}$ emissions in Southern Brazil (Costa et al., 2008; Siqueira Neto et al., 2009). Franzluebbers et al. (1995) conducted a long-term experiment in the South-Central region of Texas, USA, with a mean annual temperature of $20^{\circ} \mathrm{C}$ and mean precipitation of $1,000 \mathrm{~mm}$ (i.e., similar climatic conditions to Southern Brazil) and reported mean annual emissions of $0.65-1.02 \mathrm{~kg} \mathrm{ha}^{-1} \mathrm{~h}^{-1} \mathrm{C}-\mathrm{CO}_{2}$, for NT with crop rotation and CT with monoculture system, respectively. In that study, a bimodal pattern of $\mathrm{C}$ $\mathrm{CO}_{2}$ emissions was noted, with a first peak associated to the maximum crop growth stage, attributed mostly to root respiration, and a second peak just after crop harvest, mainly due to the decomposition of crop residues and root senescence. In addition, SOM decomposition is an important source of $\mathrm{C}-\mathrm{CO}_{2}$ whenever climatic conditions are favorable to high biologic activity (Kuzyakov, 2006). Therefore, most of the measured soil C- $\mathrm{CO}_{2}$ emissions in the tillage and cropping systems in our study were probably originated by the heterotrophic metabolism of microorganisms during the decomposition of crop residues and autotrophic root respiration, while SOM turnover was an additional factor to total emissions (Mielnick, 1996; Campos et al., 2011).

In the present study, a bimodal pattern for the C$\mathrm{CO}_{2}$ efflux was also observed, with a first efflux peak near October/November and a second peak, higher than the first, near February/March (Figure 5). Previously, Costa et al. (2008) also reported a C-CO peak in October in a long-term experiment with tillage and crop systems in Rio Grande do Sul State. The October efflux peak was probably the result of the winter crop residue input and the February peak was mostly associated to the crop growth stage, corresponding to maximum canopy photosynthetic C$\mathrm{CO}_{2}$ assimilation and, as a consequence, high root respiration. Mielnick (1996) reported a positive linear relationship between leaf area index of maize and alfalfa with C-CO $\mathrm{CO}_{2}$ efflux. In our study, the $\mathrm{C}$ release from the input of aboveground winter crop residues (Table 1 and Figure 2), as described above, can result in a maximum theoretical efflux of $0.25-0.50 \mathrm{~kg} \mathrm{ha}^{-1}$ $\mathrm{h}^{-1} \mathrm{C}-\mathrm{CO}_{2}$ for $\mathrm{NT}$ and $\mathrm{CT}$, respectively, since a fraction of these values will be assimilated by microbial biomass and incorporated as MOS.

Generally, the C- $\mathrm{CO}_{2}$ effluxes (Figure 4) were higher in the summer and lower in the winter months, parallel to the air temperature pattern (Figure 1). A similar trend had previously been reported by Franzluebbers et al. (1995), Costa et al. (2008) and Siqueira Neto et al. (2009). However, periods with distinct patterns also occurred, e.g., between December 1999 and January 2000, when, even at high air temperatures, low $\mathrm{C}-\mathrm{CO}_{2}$ emissions were observed, probably related to low soil moisture (Figure 3). Air temperature, soil moisture and their interactions effects on soil C- $\mathrm{CO}_{2}$ emissions have been frequently reported in the literature (Kucera \& Kirkham, 1971; Franzluebbers et al., 1995; Mielnick, 1996; Moreira \& Siqueira, 2002; Costa et al., 2008; Siqueira Neto et al. (2009); Chavez et al., 2009). However, in this study, averaged across cropping systems, no significant correlation with soil moisture was observed in the $\mathrm{C}-\mathrm{CO}_{2}$ efflux from the tillage systems $\mathrm{CT}$ $(\mathrm{r}=0.135, \mathrm{p}=0.097)$ and $\mathrm{NT}(\mathrm{r}=0.011, \mathrm{p}=0.89)$. On the other hand, $\mathrm{C}-\mathrm{CO}_{2}$ emissions were weakly correlated with air temperature for both $\mathrm{CT}(\mathrm{r}=0.426, \mathrm{p}<0.001)$ and NT $(r=0.348, p<0.001)$. In a similar study, Costa et al. (2008) observed strong correlation $(r=0.88$, $\mathrm{p}<0.001)$ between $\mathrm{C}-\mathrm{CO}_{2}$ emissions and soil temperature, averaged across tillage and cropping 


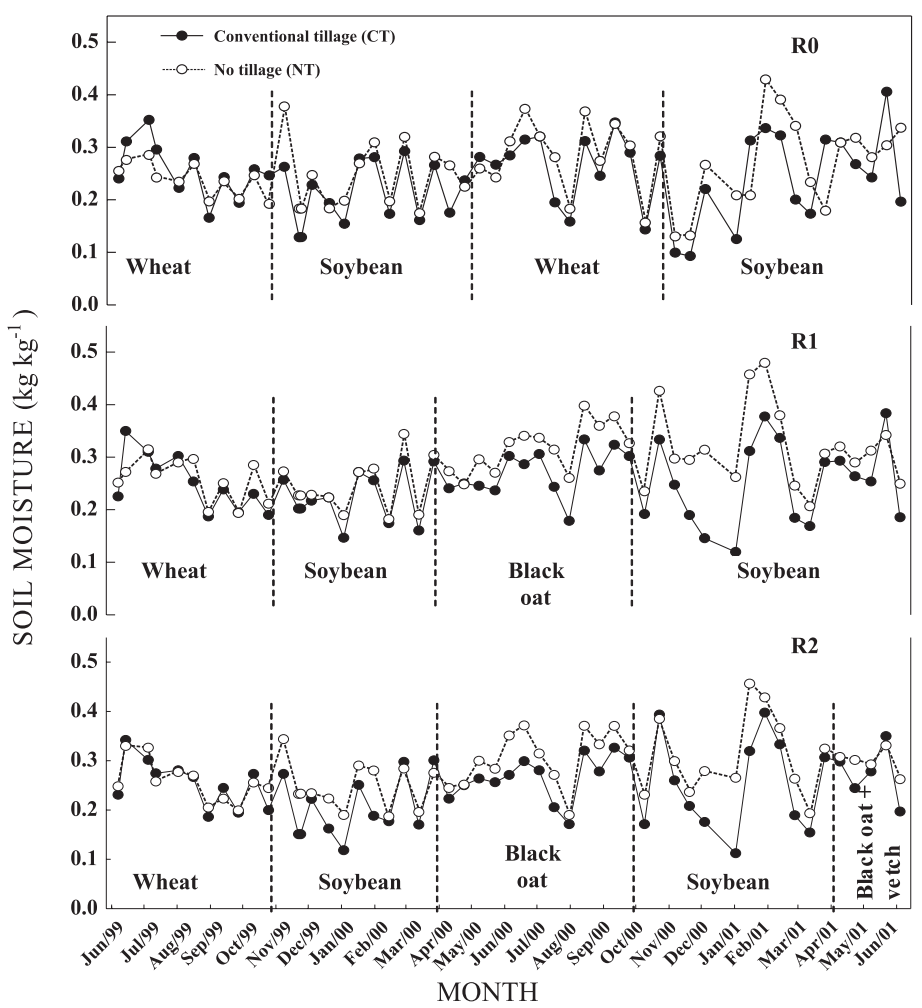

Figure 3. Soil moisture (0-0.05 m) under conventional tillage (CT) and no tillage (NT) and cropping systems (R0: soybean/wheat; R1: soybean/wheat/soybean/black oat; R2: soybean/black oat/soybean/black oat+common vetch/maize/radish oil/wheat) between 07/June/99 a 04/June/01.

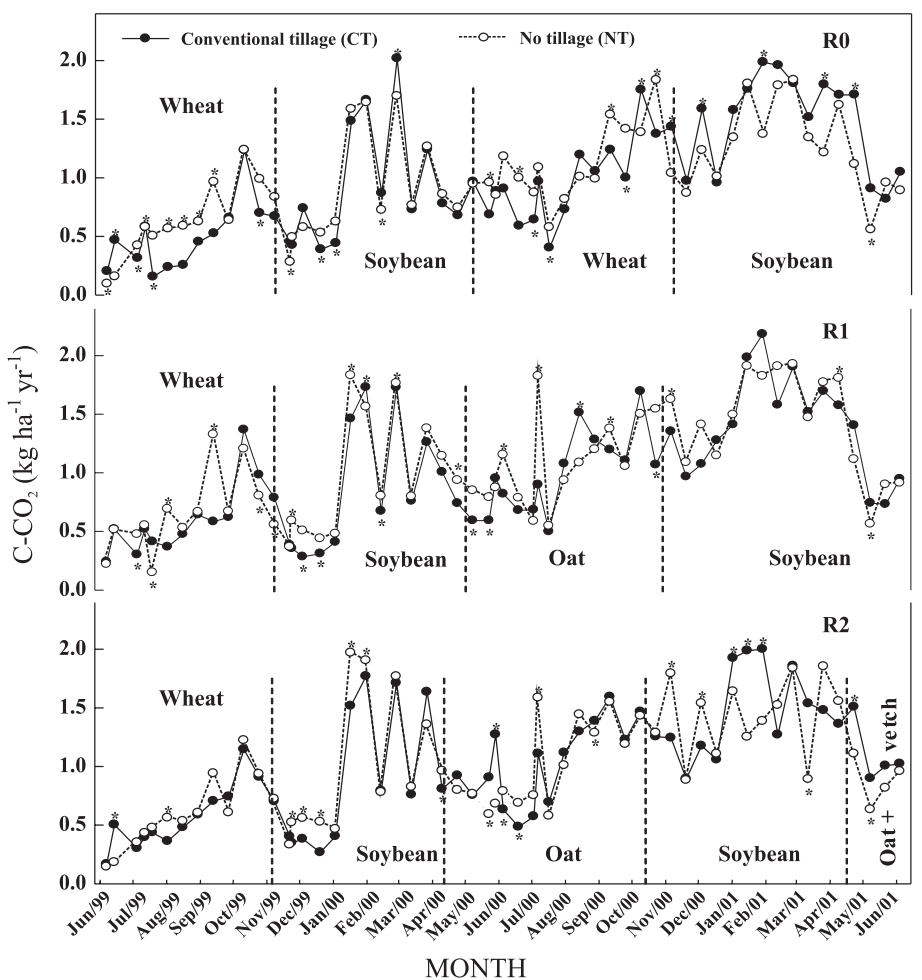

Figure 4. C-CO fluxes under conventional tillage (CT) and no tillage (NT) and cropping systems (R0: soybean/ wheat; R1: soybean/wheat/soybean/black oat; R2: soybean/black oat/soybean/black oat+common vetch/ maize/radish oil/ wheat) during $07 / J u n e / 99$ to $04 / J u n e / 01 . *=$ means statistically different by LSD test $(\mathrm{p}<0.05)$. 


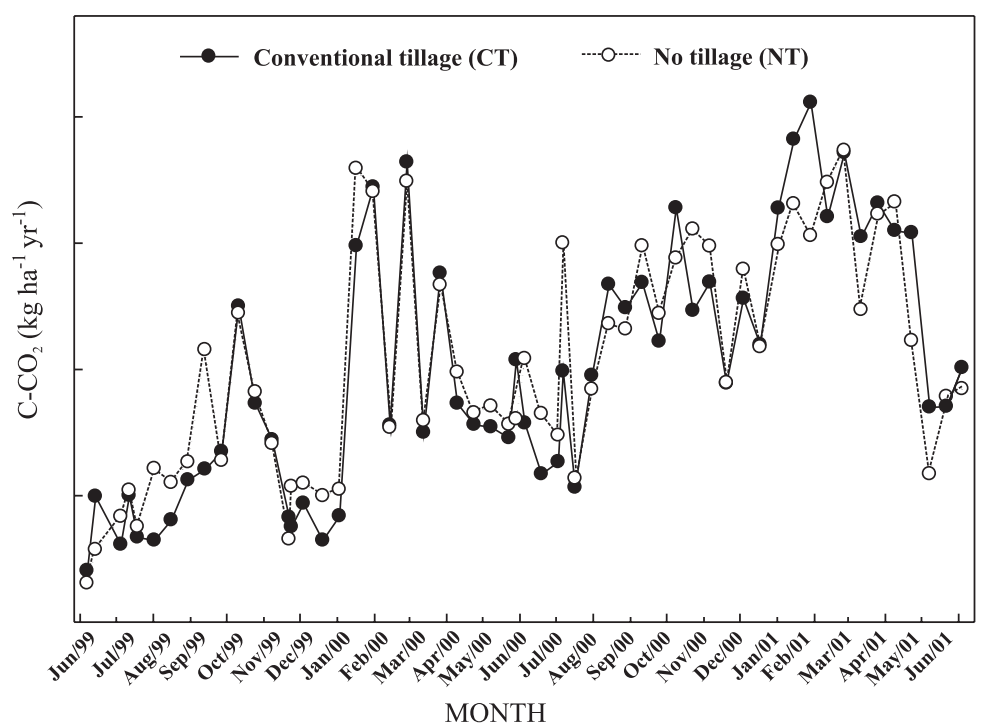

Figure 5. Monthly average peaks of $\mathrm{C}-\mathrm{CO}_{2}$ fluxes in conventional tillage (CT) and no tillage (NT) systems between June 7, 1999 and June 4, 2001.

systems, but lower correlation with soil moisture in the 0-0.05 m layer. Mielnick (1996) also reported that soil temperature was by far the most important factor in soil $\mathrm{CO}_{2}$ efflux from agricultural ecosystems.

The comparison of the two experimental periods (1999/2000 and 2000/2001) shown an average C-CO $\mathrm{CO}_{2}$ efflux 59 and $71 \%$ higher in the second than in the first year, respectively for NT and CT. The mean air temperature was similar in both periods, but the winter was cooler in the first year. In addition, rainfall was $20 \%$ higher in the second period (Figure 1). This result could indicate that in the first period the moist soil and cold winter could be limiting factors for biological activity. The relationship pattern of soil moisture and $\mathrm{C}-\mathrm{CO}_{2}$ efflux was non-linear, with a rapid decrease of biological activity whenever soil moisture was beyond the range considered ideal (Linn \& Doran, 1984). Based on C-CO2 emissions, NT was less sensitive to rapid changes on meteorological conditions than CT.

The annual C-CO $\mathrm{CO}_{2}$ efflux averaged across tillage and cropping systems ranged from 8.93 to $9.47 \mathrm{Mg} \mathrm{ha}^{-1}$ $\mathrm{yr}^{-1}$, with an average of $9.06 \mathrm{Mg} \mathrm{ha}^{-1} \mathrm{yr}^{-1}$. Franzluebbers et al. (1995) reported annual C-CO effluxes ranging from 5.85 to $8.42 \mathrm{Mg} \mathrm{ha}^{-1} \mathrm{yr}^{-1}$ in Texas, USA. Mielnick (1996) in an average of two years reported for maize growth season (June through October) efflux of 5.05 $\mathrm{Mg} \mathrm{ha}^{-1}$. Costa et al. (2008) reported annual $\mathrm{C}-\mathrm{CO}_{2}$ effluxes ranging from 3.6 to 4.0 $\mathrm{Mg} \mathrm{ha}^{-1} \mathrm{yr}^{-1}$ in Southern Brazil. Therefore, the $\mathrm{C}-\mathrm{CO}_{2}$ emissions observed in the present study were comparable to those verified by Mielnick (1996) and Franzluebbers et al. (1995) and about twice of those found by Costa et al. (2008). However, is important to highlight that Costa et al. (2008) excluded the contribution of roots to C- $\mathrm{CO}_{2}$ emissions by sampling plots that had been kept free of any vegetation and with low soil C stocks (from 27.8 to $36.1 \mathrm{Mg} \mathrm{ha}^{-1} \mathrm{C}$ ), whereas in the presented study soil C stocks were high (from 53.9 to $62.5 \mathrm{Mg} \mathrm{ha}^{-1} \mathrm{C}$ ) and plant root respiration was included in the $\mathrm{C}-\mathrm{CO}_{2}$ measurements. On the other hand, crop residue inputs and air temperature do nott explain the differences in $\mathrm{C}-\mathrm{CO}_{2}$ effluxes between these two sites: in Costa et al. (2008), study, C inputs ranged from 5.8 to $7.5 \mathrm{Mg} \mathrm{ha}^{-1} \mathrm{yr}^{-1} \mathrm{C}$ and the air temperatures were higher, whereas in the present study $\mathrm{C}$ inputs ranged from 3.3 to $5.1 \mathrm{Mg} \mathrm{ha}^{-1} \mathrm{yr}^{-1} \mathrm{C}$ with lower temperatures. Based on these observations, probably, the contribution of root respiration and biological activity of the microorganisms associated to the rhizosphere could be the main reason for the differences in $\mathrm{C}-\mathrm{CO}_{2}$ emissions verified in these two studies. Mielnick (1996) reported that the relative contribution of root plus rhizosphere to the surface $\mathrm{C}-\mathrm{CO}_{2}$ efflux was estimated to average $54 \%$ over a maize growing season. Franzluebbers et al. (1995) found a correlation between $\mathrm{C}-\mathrm{CO}_{2}$ effluxes and the amount of $\mathrm{C}$ input by crop residues $(r=0.713, p<0.001)$, but the effect of this $\mathrm{C}$ source was noted only for a short period after the crop harvest. The same study found no correlation between $\mathrm{C}-\mathrm{CO}_{2}$ emissions and soil $\mathrm{C}$ stock.

\section{Soil carbon conservation indexes}

With the purpose of evaluating the efficiency of tillage and cropping system in soil $\mathrm{C}$ conservation, four indexes based on the relationship of soil organic carbon (SOC) and its compartments with annual C$\mathrm{CO}_{2}$ emissions and $\mathrm{C}$ input were investigated in this study (Table 2). The ratio of change in soil $\mathrm{C}$ stock by the amount of $\mathrm{C}$ crop residue input (CCI I) ranged from 3 to $14 \%$. The higher this relationship, the more efficient the management system will be in soil $\mathrm{C}$ conservation. Both tillage and cropping systems had an effect on this ratio, which was higher for NT and 
crop rotation than for CT and monoculture. In addition, the crop rotation effect was more pronounced than the tillage effect. Beside the quantity of $\mathrm{C}$ input, the quality of crop residues was important for increases in soil C stock (Lovato et al., 2004; Amado et al., 2006; Campos et al., 2011). Franzluebbers et al. (1995) reported values ranging from 9 to $25 \%$ for these indexes, with the highest values also observed under NT and crop rotation.

The ratio of annual C- $\mathrm{CO}_{2}$ efflux by $\mathrm{C}$ stocks in the $0-0.20 \mathrm{~m}$ layer (CCI II) was similar among tillage and cropping systems, ranging from $15 \%$ (NT R2) to $17 \%$ (CT R0). These results were lower and the range narrower than found by Franzluebbers et al. (1995) who reported values ranging from $20 \%$ (NT with crop rotation) to $35 \%$ (CT with soybean/wheat succession), but higher than mentioned by Costa et al. (2008), who found a range from $10.2 \%$ (NT maize/common vetch) to $13.5 \%$ (CT maize/black oat). In general, in these studies (Franzluebers et al. (1995), Costa et al. (2008), and in our study, CCI II under NT and crop rotation was higher than under $\mathrm{CT}$ and monoculture. The CCI III was more sensitive to the effects of tillage and crop systems than CCI II. This result was expected since the soil residence time of particulate $\mathrm{C}$ is shorter than of SOC (Kuzyakov, 2006) and therefore this pool should have a higher relative contribution to annual $\mathrm{C}-\mathrm{CO}_{2}$ efflux. The increase in POC pool associated to conservation system (Campos et al., 2011) did not increase the $\mathrm{C}-\mathrm{CO}_{2}$ emission in the same proportion, since the improvement in soil management (NT and crop rotation) decreased the CCI III index.

The relationship between annual C-CO $\mathrm{CO}_{2}$ efflux and the sum of soil $\mathrm{C}$ stock and $\mathrm{C}$ input by annual crop residues (CCI IV) indicate similar results across tillage and cropping systems, ranging from 14 to $15 \%$. Franzluebbers et al. (1995) found values ranging from 17.4 to $27.0 \%$ and Costa et al. (2008) reported values ranging from 9.5 to $11.5 \%$. In the cited studies, the lowest ratio was observed under NT and crop rotation. This index is negatively related to the potential of soil $\mathrm{C}$ conservation. The lack of sensitivity of CCI II to tillage and crop systems in the present study could be associated to the soil characteristics. The Red Oxisol had high contents of iron and aluminum oxides, inducing higher $\mathrm{C}$ stabilization, protecting MOS from microbial decomposition and making it less sensitive to soil management, in comparison to other soils with low oxide contents (Bayer et al., 2006a,b). Additionally, a higher proportion of recalcitrant MOS fractions in the Red Oxisol could explain the smaller differences in this index across tillage and cropping systems as compared to an Alfisol (Costa et al., 2008) and especially to an Inceptisol (Franzluebbers et al., 1995).

\section{CONCLUSIONS}

1. The crop residue $\mathrm{C}$ mineralization in time followed the exponential model, regardless of the crop residue type. For wheat, maize and black oat, C mineralization was higher in conventional tillage than in no-tillage and similar in both systems for soybean.

2. During the $\mathrm{C}-\mathrm{CO}_{2}$ efflux measurement period, soil moisture was higher in no-till than in conventional tillage; the difference in $\mathrm{C}-\mathrm{CO}_{2}$ efflux between tillage systems was amplified in the second year, with higher precipitation.

Table 2. Carbon conservation indexes under conventional tillage and no tillage and different crop rotation systems. Soil C stocks were calculated by Campos et al. (2011). C-CO $\mathrm{CO}_{2}$ effluxes were not statistically different between the soil tillage systems

\begin{tabular}{|c|c|c|c|c|c|c|c|}
\hline \multirow{3}{*}{$\begin{array}{l}\text { Cropping } \\
\text { rotation }\end{array}$} & \multicolumn{7}{|c|}{ Carbon conservation index } \\
\hline & \multirow{2}{*}{$\begin{array}{c}\text { Annual } \\
\mathrm{C}-\mathrm{CO}_{2} \text { Efflux }\end{array}$} & \multirow{2}{*}{ SOC } & \multirow{2}{*}{ Annual C-input } & \multirow{2}{*}{$\frac{\text { Ratio } \Delta \text { SOC }}{\text { C-input }}$} & \multicolumn{3}{|c|}{ Ratio C-CO ${ }_{2}$} \\
\hline & & & & & SOC & POC & SOC + C-input \\
\hline & 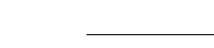 & \multirow{2}{*}{\multicolumn{6}{|c|}{ Conventional tillage }} \\
\hline & & & & & & & \\
\hline Monocrop & 8.95 & 53.98 & 4.01 & 0.03 & 0.17 & 3.54 & 0.15 \\
\hline Winter & 9.06 & 56.62 & 4.60 & 0.06 & 0.16 & 2.67 & 0.15 \\
\hline \multirow[t]{2}{*}{ Intensive } & 8.90 & 59.76 & 3.32 & 0.13 & 0.15 & 2.64 & 0.14 \\
\hline & & & & No tillage & & & \\
\hline Monocrop & 8.93 & 55.03 & 3.62 & 0.05 & 0.16 & 2.33 & 0.15 \\
\hline Winter & 9.03 & 58.90 & 5.12 & 0.08 & 0.15 & 2.19 & 0.14 \\
\hline Intensive & 9.47 & 62.49 & 4.14 & 0.14 & 0.15 & 2.19 & 0.14 \\
\hline
\end{tabular}

Annual C-CO $\mathrm{CO}_{2}$ emissions: mean annual emissions determined between 1999 and 2001. SOC: soil organic carbon stocks of the 0$0.20 \mathrm{~m}$ depth determined by Campos et al. (2011). POC: particulate organic carbon stocks of the 0-0.10 m depth shown in Table 2 in Campos et al. (2011). Annual C input: above-ground C input $+30 \%$ for root contribution. D SOC: change of SOC stocks in the 0-0.20m layer between 1985 and 2004 (Campos et al., 2011). Monocrop: sucession of wheat/soybean. Winter crop rotation: wheat/soybean/black oat/soybean. Intensive crop rotation: black oat/soybean/black oat+common vetch /maize/oilseed radish/ wheat /soybean. 
3. The annual average of $\mathrm{C}-\mathrm{CO}_{2}$ efflux did not differ between conventional and no-tillage systems. Only some individual $\mathrm{C}-\mathrm{CO}_{2}$ efflux evaluations differed between tillage systems.

4. The $\mathrm{C}-\mathrm{CO}_{2}$ efflux followed a bimodal pattern with a first peak in October/November and a second, more intense, in February/March. The highest emission was recorded in the summer and the lowest in the winter. The $\mathrm{C}-\mathrm{CO}_{2}$ effluxes were correlated to air temperature but not influenced by soil moisture.

5. Based on the soil conservation indexes investigated, $\mathrm{C}$ conservation in no-till associated to crop rotation was higher than in conventional tillage with monoculture. The change ratio in soil $\mathrm{C}$ stock per unit of $\mathrm{C}$ input by crop residues was increased with the cropping system diversification, regardless of soil tillage.

\section{LITERATURE CITED}

AITA, C. \& GIACOMINI, S.J. Matéria orgânica do solo, nitrogênio e enxofre nos diversos sistemas de exploração agrícola: Plantio direto x plantio convencional. In: YAMADA, T.; STIPP E ABDALLA, S.R. \& VITTI, G.C., eds. Nitrogênio e enxofre na agricultura brasileira. Piracicaba, ESALQ/São Paulo, IPNI - International Plant Nutrition Institute, 2007. p.1-41.

AMADO, T.J.C.; MATOS, A.T. \& TORRES, L. Flutuação de temperatura e umidade do solo sob preparo convencional e em faixas na cultura da cebola. Pesq. Agropec. Bras., 25:625-631, 1990.

AMADO, T.J.C.; SANTI, A. \& ACOSTA, J.A.A. Adubação nitrogenada na aveia preta. II - Influência na decomposição de resíduos, liberação de nitrogênio e rendimento de milho sob sistema plantio direto. R. Bras. Ci. Solo, 27:1085-1096, 2003.

AMADO, T.J.C.; BAYER, C.; CONCEIÇÃO, P.C.; SPAGNOLLO, E.; CAMPOS, B.C. \& VEIGA, M. Potential of carbon accumulation in no-till soils with intensive use and cover crops in Southern Brazil. J. Environ. Quality, 35:1599-1607, 2006.

ANDERSON, J.P.E. Soil respiration. In: PAGE, A.L., ed. Methods of soil analysis. Madison, American Society of Agronomy, 1982. p.831-871.

BAYER, C.; MIELNICZUK, J. \& MARTIN SIQUEIRA NETO, L. Efeito de sistemas de preparo e de cultura na dinâmica da matéria orgânica e na mitigação das emissões de $\mathrm{CO}_{2}$. R. Bras. Ci. Solo, 24:599-607, 2000.

BAYER, C.; MARTIN-SIQUEIRA NETO, L.; MIELNICZUK, J.; PAVINATTO, A. \& DIECKOW, J. Carbon sequestration in two Brazilian Cerrado soils under no-till. Soil Tillage Res., 86:237-245, 2006a.
BAYER, C.; MARTIN-SIQUEIRA NETO, L.; MIELNICZUK, J.; PAVINATTO, A.; DIECKOW, J. \& AMADO, T.J.C. C and $\mathrm{N}$ stocks and the role of molecular recalcitrance and organomineral interaction in stabilizing soil organic matter in a subtropical acrisol managed under no-tillage. Geoderma, 133:258-268, 2006b.

BRADY, N.C. Natureza e propriedade dos solos. São Paulo, Mcgraw-Hill, 1989. 878p.

BRASIL decidirá sobre proposta de emissões no dia 14. Acess under: < http://www.portaldomeioambiente.org.br/ assuntos-gerais/2306-brasil-decidira-sobre-proposta -deemissoes-no-dia-14.html>. Access date: Dec. 12, 2009.

BUYANOVSKY, G.A.; WAGNER, G.H. \& GANTZER, C.J. Soil respiration in a winter wheat ecosystem. Soil Sci. Soc. Am. J., 50:338-344, 1986.

CAMPBELL, C.A.; BIERDENBECK, V.O.; ZENTNER, R.P. \& LAFOND, G.P. Effect of crop rotations and cultural practices on soil organic matter, microbial biomass and respiration in a Thin Black Chernozem. Canadian J. Soil Sci., 71:363-376, 1991.

CAMPOS, B.C. Dinâmica do carbono em Latossolo Vermelho sob sistemas de preparo de solo e de culturas. Santa Maria, Universidade Federal de Santa Maria, 2006. 188p. (Tese de Doutorado)

CAMPOS, B.C.; AMADO, T.J.C.; BAYER, C.; NICOLOSO, R.S. \& FIORIN, J.E. Atmospheric carbon retention in a subtropical Red Oxisol under tillage systems and crop rotations. R. Bras. Ci. Solo, 35: ???-??? PAG. 044-10.

CANALLI, L.B.S. Decomposição de resíduos culturais e sua contribuição nos macroagregados e na fração lábil da matéria orgânica do solo no sistema plantio direto. Curitiba, Universidade Federal do Paraná, 2009. 109p. (Tese de Doutorado)

CERRI, C.C. \& CERRI, C.E.P. Seqüestro de carbono em solos na América Latina. B. Inf. SBCS, 32:40-44, 2007.

CHAVEZ, L.F.; AMADO, T.J.C.; BAYER, C.; LA SCALA, N.J.; ESCOBAR, L.F.; FIORIN, J.E. \& CAMPOS, B.C. Carbon dioxide efflux in a Rhodic Hapludox as affected by tillage systems in Southern Brazil. R. Bras. Ci. Solo, 33:325-334, 2009 .

CONCEIÇÃO, P.C.; AMADO, T.J.C.; MIELNICZUK, J. \& SPAGNOLLO, E. Qualidade do solo em sistemas de manejo avaliada pela dinâmica da matéria orgânica e atributos relacionados. R. Bras. Ci. Solo, 29:777-788, 2005.

COSTA, F.S.; GOMES, J.; BAYER, C. \& MIELNICZUK, J. Métodos para avaliação das emissões de gases do efeito estufa no sistema solo-atmosfera. Ci. Rural, 36:693-700, 2006.

COSTA, F.S.; BAYER, C.; ZANATTA, J.A. \& MIELNICZUK, J. Estoque de carbono orgânico no solo e emissões de dióxido de carbono influenciadas por sistemas de manejo no sul do Brasil. R. Bras. Ci. Solo, 32:323-332, 2008.

DA ROS, C.O. Dinâmica do carbono e do nitrogênio com o uso de uréia, na sucessão aveia preta/milho, no sistema plantio direto. Santa Maria, Universidade Federal de Santa Maria. 2004. 129p. (Tese de Doutorado) 
DE BONA, F.D.; BAYER, C.; BERGAMASCHI, H. \& DIEKOW, J. Carbono orgânico no solo em sistemas irrigados por aspersão sob plantio direto e preparo convencional. R. Bras. Ci. Solo, 30:911-920, 2006

DIXON, W.J. Analysis of extreme values. Ann. Mathem. Stat., 21:488-506, 1950.

EMPRESA BRASILEIRA DE PESQUISA AGROPECUÁRIA EMBRAPA. Centro Nacional de Pesquisa de Solos. Sistema brasileiro de classificação de solos. Brasília, Embrapa Produção de Informação, 1999. 412p.

FRANZLUEBBERS, A.J.; HONS, F.M. \& ZUBERER, D.A. Long-term changes in soil carbon and nitrogen pools in wheat management systems. Soil Sci. Soc. Am. J., 58:1639. 1645,1994

FRANZLUEBBERS, A.J.; HONS, F.M. \& ZUBERER, D.A. Tillage-induced seasonal changes in soil physical properties affecting soil $\mathrm{CO}_{2}$ evolution under intensive cropping. Soil Tillage Res., 34:41-60, 1995.

KUCERA, C.L. \& KIRKHAM, D.R. Soil respiration studies in tallgrass prairie in Missouri. Ecology, 52:912-915, 1971.

KUZYAKOV, Y. Sources of $\mathrm{CO}_{2}$ efflux from soil and review of partitioning methods. Soil Biol. Biochem., 38:425-448, 2006.

INTERGOVERNMENTAL PANEL ON CLIMATE CHANGE IPCC. Climate Change 2001: Contribution of working group I to the third assessment report of the intergovernmental panel on climate change. Cambridge, Cambridge University Press, 2001. 881p.

INTERGOVERNMENTAL PANEL ON CLIMATE CHANGE IPCC. Climate Change 2007: The physical science basis. Contribution of working group I to the fourth assessment report of the intergovernmental panel on climate change. Cambridge, Cambridge University Press, 2007.

LINN, D.M. \& DORAN, J.W. Effect of water-filled pore space on carbon dioxide and nitrous oxide production in tilled and nontilled soils. Soil Sci. Soc. Am. J., 48:1267-1272, 1984.

LOVATO, T.; MIELNICZUK, J.; BAYER, C. \& VEZZANI, F. Adição de carbono e nitrogênio e sua relação com os estoques no solo e com o rendimento do milho em sistemas de manejo. R. Bras. Ci. Solo, 28:175-187, 2004.

MAGID, J.; MUELLER, T.; JENSEN, L.S. \& NIELSEN, N.E. Modelling the measurable: Interpretations of field-scale $\mathrm{CO}_{2}, \mathrm{~N}$-mineralization, soil microbial biomass and light fractions as indicators of oilseed rape, maize and barley straw decomposition. In: CADISCH, G. \& GILLER, K.E., eds. Driven by nature: Plant litter quality and decomposition. Wallingford, CAB International, 1997. p.349-362.

MANLAY, R.; FELLER. C. \& SWIFT, M.J. Historical evolution of soil organic matter concepts and their relationships with the fertility and sustainability of cropping systems. Agric. Ecosyst. Environ., 119:217-233, 2007.

MOREIRA, F.M.S. \& SIQUEIRA, J.O. Microbiologia e bioquímica do solo. Lavras, Universidade Federal de Lavras, 2002. 626p.
MORENO, J.A. Clima do Rio Grande do Sul. Porto Alegre, Secretaria da Agricultura, Seç̧ão de Geografia, 1961. 38p.

MIELNICK, P.C. Soil carbon dioxide flux in agricultural ecosystems. Lincoln, University of Nebraska. 1996. 86p. (Tese de Doutorado)

PADOVAN, M.P.; ALMEIDA, D.L.; GUERRA, J.G.M.; RIBEIRO, R.L.D.; OLIVEIRA, F.L.; SANTOS, L.A.; ALVES, F.A.; RODRIGUES, B.J. \& SOUTO, S.M. Decomposição e liberação de nutrientes de soja cortada em diferentes estádios de desenvolvimento. Pesq. Agropec. Bras., 41:667-672, 2006.

PAUL, E.A. \& CLARK, F.E. Soil microbiology and biochemistry. San Diego, Academic Press, 1989. 275p.

REES, R.M.; BINGHAM, I.J.; BADDELEY, J.A. \& WATSON, C.A. The role of plants and land management in sequestering soil carbon in temperate arable and grassland ecosystems. Geoderma, 128:130-154, 2005.

RUEDELL, J. Plantio direto na região de Cruz Alta. Cruz Alta, FUNDACEP, 1995. 134p.

SAS Institute. The SAS System For Windows Release 6.12 (Software). Cary, 1996.

SIQUEIRA NETO, M.; PICCOLO, M.C.; FEIGL, B.J.; VENZKE FILHO, S.P.; CERRI, C.E.P. \& CERRI, C.C. Rotação de culturas no sistema plantio direto em Tibagi (PR).II Emissões de $\mathrm{CO}_{2}$ e $\mathrm{N}_{2} \mathrm{O}$. R. Bras. Ci. Solo, 33:1023-1029, 2009 .

SIQUEIRA, O.J.W.; STEINMETZ, S. \& SALLES, L.A.B. Efeitos potenciais das mudanças climáticas na agricultura brasileira e estratégias adaptativas para algumas culturas. In: LIMA, M.A.; CABRAL, O.M.R. \& MIGUEZ, J.D.G., eds. Mudanças climáticas globais e a agropecuária brasileira. Jaguariúna, Embrapa Meio Ambiente, 2001. p.33-64.

STEVENSON, F.J. Humus chemistry: Genesis, composition, reactions. 2.ed. New York, J. Wiley, 1994. 496p.

STOTZKY, G. Microbial respiration. In: BLACK, C.A., ed. Methods of soil analysis. Madison, American Society of Agronomy, 1956. Part 2. p.1550-1572.

STRECK, N.A. Climate change and agroecosystems: The effect of elevated atmospheric $\mathrm{CO}_{2}$ and temperature on crop growth, development and yield. Ci. Rural, 35:730-740, 2005 .

SYSTAT Software. Sigmaplot 11. San Jose, Califórnia, 2002.

TEDESCO, M.J.; GIANELLO, C.; BISSANI, C.A.; BOHNEN, H. \& VOLKWEISS, S.J. Análises de solo, plantas e outros materiais. 2.ed. Porto Alegre, Universidade Federal do Rio Grande do Sul, 1995. 174p. (Boletim Técnico, 5)

VARGAS, L.K. \& SCHOLLES, D. Biomassa microbiana e produção de $\mathrm{C}-\mathrm{CO}_{2}$ e $\mathrm{N}$ mineral de um Podzólico Vermelho-escuro submetido a diferentes sistemas de manejo. R. Bras. Ci. Solo, 24:35-42, 2000.

WEST, T.O. \& POST, W.M. Soil organic carbon sequestration rates by tillage and crop rotation: A global data analysis. Soil Sci. Soc. Am. J., 66:1930-1946, 2002. 
WHITMORE, A.P. Describing the mineralization of carbon added to soil in crop residues using second-order kinetics. Soil Biol. Biochem., 28:1435-1442, 1996.

WIEDER, R.K. \& LANG, G.E. A critique of the analytical methods used in examining decomposition data obtained from litter bags. Ecology, 63:1636-1642, 1982.
ZANATTA, J.A.; BAYER, C.; DIECKOW, J.; VIEIRA, F.C.B.; COSTA BEBER, F. \& MIELNICZUK, J. Soil organic carbon accumulation and carbon costs related tillage, cropping systems and nitrogen fertilization in a subtropical Acrisol. Soil Tillage Res., 94:510-519, 2007. 